\title{
ANALISIS BREAK EVEN POINT SEBAGAI ALAT PROFIT PLANNING PADA HOTEL WIJAYA SUKABUMI
}

\section{BREAK EVEN POINT ANALYSIS AS A PROFIT PLANNING TOOL IN HOTEL WIJAYA SUKABUMI}

\author{
Moch Yusuf Guntara Maulidin', Andri Indrawan ${ }^{2}$, Ade Sudarma ${ }^{3}$ \\ Universitas Muhammadiyah Sukabumi ${ }^{1,2,3}$ \\ yuguntara17@gmail.com ${ }^{1}$
}

\begin{abstract}
This research is based on the importance of the management of a company and to know the implement of break event point analysis and the margin of safety in which to study and explore the relationship between costs, profits, and volume of activities. This study aims to determine the break event point approach and the margin of safety as a basis in profit planning. The variables used in this study are Break Event Point and Margin of Safety. The population and sample used are social conditions consisting of three components; places, actors, and activities, with a sampling technique using purposive sampling. Resource persons in the study are the owners, managers, and accountants. This research uses a qualitative method with a descriptive approach. Based on the results of research that Hotel Wijaya in 2018 and 2019 has reached the level of break even point. Margin of safety for 2016 was $41 \%$, in 2017 it was $21 \%$, in 2018 it was $39 \%$ and in 2019 it was 35\%, while in 2020 Hotel Wijaya planned profit with a percentage of $10 \%$ with a total of 104,764,000. Thus, to obtain the profit the Wijaya Hotel must be able to rent out rooms with sales of Rp 355,832,589 with as many as 4,211 units sold. So it can be concluded that the growth of assets and leverage only affects $1.4 \%$ of the dividend policy and the rest is influenced by other factors not examined in this study.
\end{abstract}

Keywords: Break Even Point, Profit Planning

\begin{abstract}
ABSTRAK
Penelitian ini didasari pada pentingnya pihak manajemen suatu perusahaan untuk mengetahui dan melakukan penerapan analisis break event point yang mana didalamnya mempelajari dan mendalami hubungan antara biaya, keuntungan, serta volume aktivitas. Penelitian ini bertujuan untuk mengetahui pendekatan break event point sebagai dasar dalam profit planning. Variabel yang digunakan dalam penelitian ini adalah Break Event Point. Populasi dan sampel yang digunakan adalah kondisi social yang terdiri dari tiga komponen; tempat, pelaku, dan aktivitas, dengan teknik pengambilan sampel menggunakan purposive sampling. Narasumber dalam penelitian yaitu pemilik, manajer, dan akuntan. Penelitian ini menggunakan metode kualitatif dengan pendekatan deskriptif. Berdasarkan hasil penelitan bahwa Hotel Wijaya pada tahun 2018 dan 2019 telah mencapai tingkat break even point. Perencanaan laba pada tahun 2020 Hotel Wijaya merencanakan laba dengan persentase sebesar $10 \%$ dengan jumlah sebesar 104,764,000. Dengan demikian, untuk memperoleh laba tersebut Hotel Wijaya harus
\end{abstract}


bisa menyewakan kamar dengan penjualan sebesar Rp 355,832,589 dengan unit terjual sebanyak 4.211 unit.

Kata Kunci: Titik Impas, Perencanaan Laba.

\section{PENDAHULUAN}

Tujuan final dari suatu perusahaan yakni menjaga dan mengoptimalkan keuntungan.

Memperoleh keuntungan kerap kali menjadi indikator kesuksesan suatu manajemen, dimana dalam prosesnya memerlukan planning yang benar. sehingga untuk menggapai tujuan yang dikehendaki pihak manajemen perlu merumuskan planning supaya sumber daya yang terdapat dalam perusahaan dapat diarahkan secara teratasi dan terkendali. Hal ini ditunjang oleh kecakapan pihak manajemen dalam memprediksi peluang serta kesempatan di periode yang akan datang.

Keberhasilan suatu usaha tidak diperoleh secara otomatis, akan tetapi harus memakai strategi dalam menghadapi persaingan di pangsa pasar. Salah satu strategi yang bisa digunakan yaitu dengan profit planning. biasanya dikelola oleh pihak manajemen hotel khususnya manajer hotel. Profit planning ialah tahapan-tahapan yang akan ditempuh oleh perusahaan untuk mencapai besarnya target laba yang diharapkan. Laba ialah tujuan pokok perusahaan, maka dari itu pihak manajemen harus melakukan profit planning pada produk atau jasa yang akan dijual. Dalam merencanakannya perlu melakukan peninjauan laba, harga jual, serta penjualan (Sujarweni, 2019).

Rencana laba berisi gambaran keuangan yang bersifat naratif mengenai hasil yang diharapkan dari implementasi keputusan (Adisaputro \& Anggraini, 2017). Dikarenakan profit ialah selisih antara pemasukan yang diperoleh dari hasil penjualan dengan beban yang dikeluarkan, maka profit planning dipengaruhi oleh rencana penjualan dan rencana biaya. Dalam merumuskan profit planning yang tepat memerlukan alat bantu berupa analisis titik impas (break even point) yang mana bagian dari analisis cost volume profit (Romanda, 2017). "Analisis cost volume profit merupakan suatu alat yang sangat berguna untuk perencanaan dan pengambilan keputusan" (Hansen \& Mowen, 2009)

BEP merupakan salah satu alat untuk membuat perencanaan laba" (Utari et al., 2016). Analisis break even dapat digunakan pihak manajemen sebagai teknik planning, control, decision making dalam aktivitas perusahaan untuk mencapai laba, serta menyongsong perubahan yang mungkin terjadi atas, harga penjualan dan biaya yang dikeluarkan. Jika suatu perusahaan dideteksi break event-nya, maka dapat memudahkan pihak manajemen dalam merumuskan profit planning, meminimalkan kerugian, memaksimalkan keuntungan, dan membuat ramalan keuntungan yang diinginkan. Sekalipun pihak manajemen melakukan profit planning setiap tahun, namun biasanya sangat memperhatikan break event-nya. Bilamana tingkat penjualan berada dibawah titik impas, maka disebut kerugian. Break even dapat berasaskan pada informasi historis, operasi masa lampau, atau penjualan serta biaya yang diantisipasi (Sunanto, 2016).

Dalam jasa perhotelan, emiten berusaha untuk mengupayakan bagaimana menghasilkan serta mempromosikan bermacam-macam jasa yang ada didalamnya untuk pemakai yang membutuhkan. Salah satu 
penghasilan inti dari emiten jasa perhotelan ialah tingkat kepadatan hunian kamar yang serta merta memengaruhi keuntungan hotel. Pertumbuhan hotel di Indonesia terusmenerus meningkat juga memberi kontribusi yang cukup besar terhadap pendapatan Negara. Menurut data dari Badan Pusat Statistik pada tahun 2017 terdapat sekitar 18.350-an hotel yang ada di Indonesia. Total hotel yang ada di Indonesia secara terus-menerus berkembang dan mengalami pertumbuhan dari tahun tahun ke tahun.

Pertumbuhan dan Perkembangan hotel juga berlangsung di beberapa daerah di Indonesia salah satunya di Kota Sukabumi. Hotel yang terdapat di Kota Sukabumi cukup berkembang pesat dan hampir di setiap penjuru kota terdapat hotel. Di kabupaten Sukabumi terdapat 140 hotel sedangkan untuk wilayah Kota Sukabumi terdapat 37 hotel (Dinas Pariwisata Kabupaten Sukabumi/Tourism Department, 2020). Kepadatan jumlah hotel yang ada akan berdampak sulit untuk memprediksi volume penjualan yang dimilikinya dikarenakan tingkat hunian hotel dihadapkan pada ketidakpastian.

Salah satu hotel yang ada di Kota Sukabumi ialah Hotel Wijaya yang berada di pusat Kota Sukabumi tepatnya beralamat di Jl. Manggis I No. 10-18. Hotel Wijaya merupakan jenis emiten jasa perhotelan berbasis melati yang dikelola secara turun temurun, hotel ini sudah berdiri cukup lama dari tahun 60-an dan mampu bertahan sampai sekarang.

Berdasarkan tahap pengamatan awal yang dilakukan peneliti pada tanggal 20 Maret 2020 melalui wawancara secara langsung dengan pemilik usaha bahwa pihak manajemen Hotel Wijaya belum menerapkan analisis Break Even Point, manajer hanya sekadar menggunakan insting dalam menentukan laba yang ditargetkan dan belum melakukan rancangan perhitungan yang tepat akurat. Keuntungan yang diperoleh setiap tahun hanya mampu menutupi aktivitas operasional sedangkan menjadi suatu keharusan hotel untuk melakukan perbaikan serta renovasi agar meningkatkan kepuasan dan kenyamanan bagi pemakai. Masih dalam pengamatan pada tanggal 20 Maret 2020, berdasarkan informasi secara melihat langsung bukti pembukuan Hotel Wijaya bahwa tidak terdapat pemisahan biaya-biaya, baik fixed cost ataupun variable cost. Dari data yang diperoleh terbukti bahwa Hotel Wijaya tidak menggunakan analisis titik impas dalam merencanakan laba usaha.

\section{METODE PENELITIAN}

Dalam penelitian ini yang menjadi objek penelitian yaitu perencanaan laba (profit planning) dengan pendekatan analisis break even point. Metode yang digunakan dalam penelitian ini adalah metode kualitatif dengan pendekatan deskriptif.

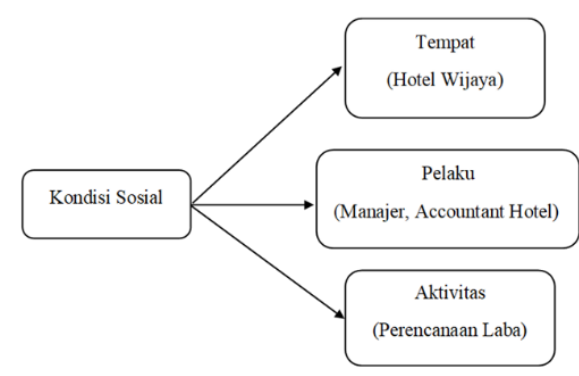

\section{Gambar 1 Populasi Penelitian (Social Situasion)}

Teknik pengambilan sampel dalam penelitian ini yaitu purposive sampling. Adapun yang menjadi sampel dalam penelitian ini adalah Manajer Hotel dan Akuntan Hotel.

Dalam penelitian ini menggunakan teknik triangulasi. 


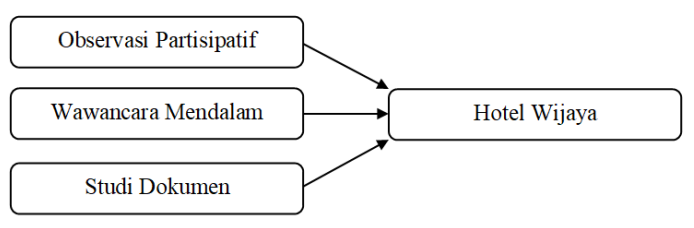

Gambar 2 Teknik Pengumpulan Data

\section{Analisis Data Pra Lapangan}

1. Melakukan pemisahan (klasifikasi) semua biaya-biaya yang dikeluarkan ke dalam dua komponen yaitu fixed cost dan variable cost.

2. Analisis break even point. Rumus perhitungan analisis break even point

$$
\begin{aligned}
& \text { BEP (Dalam Unit) }=\frac{\text { Biaya Tetap }}{\text { Margin Kontribusi Per Unit }} \\
& \text { BEP (Dalam Rupiah) }=\frac{\text { Biaya Tetap }}{\text { Rasio Margin Kontribusi }}
\end{aligned}
$$

3. Analisis Profit Planning, Rumus perhitungan analisis profit planning adalah sebagai berikut:

Penjualan $=$ Beban Variabel + Beban Tetap + Laba

\section{Reduksi Data}

Yang menjadi fokus reduksi data dalam penelitian ini yaitu mengenai data biaya operasional, total penjualan kamar, harga jual kamar volume penjualan kamar dalam unit serta data tambahan yang akan dibutuhkan ketika dilapangan.

\section{Display Data}

Penyajian data dalam penelitian ini yaitu melakukan perhitungan dan menguraikan ke dalam bentuk table dan akan diuraikan kembali selanjutnya dilakukan perhitungan dengan menggunaan rumus yang sesuai dengan analisis data sebelum dilapangan.

\section{Kesimpulan dan Verifikasi}

Dalam tahap ini apabila kesimpulan telah diverifikasi dengan didukung oleh fakta-fakta serta bukti yang valid dan konsisten maka dinyatakan kredibel. Selanjutnya dapat ditarik kesimpulan akhir dari penelitian berdasarkan rumusan masalah yang telah disusun sejak awal. Dalam penelitian ini dengan melakukan triangulasi data yang mana dengan ketiga teknik ini akan memperoleh data yang valid dan kredibel.

\section{HASIL DAN PEMBAHASAN}

\section{Tabel 1 Data Penelitian}

\begin{tabular}{lll}
\hline Tipe Kamar & $\mathbf{2 0 1 8}$ & $\mathbf{2 0 1 9}$ \\
\hline Junior Room & 392 & 323 \\
\hline Single Room & 1735 & 1945 \\
\hline Mini Standard Room & 455 & 365 \\
\hline Standard Room & 1521 & 1479 \\
\hline Total & 4103 & 4112 \\
\hline
\end{tabular}

Sumber: Hotel Wijaya (diolah)

Berdasarkan tabel diatas maka dapat diuraikan bahwa kamar yang terjual penjualan kamar pada tahun 208 sebesar 4103 kemudian pada tahun 2019 mengalami kenaikan menjadi 4112 unit yang terjual, naiknya penjualan kamar disebabkan tipe kamar Single Room mengalami kenaikan sebanyak 210 unit.

Tabel 2 Data Pendapatan Tahun 2018 dan 2019

\begin{tabular}{|l|l|l|}
\hline Tipe Kamar & $\mathbf{2 0 1 8}$ & $\mathbf{2 0 1 9}$ \\
\hline Junior Room & $23,520,000$ & $19,380,000$ \\
\hline Single Room & $130,125,000$ & $145,875,000$ \\
\hline Mini Standard Room & $38,675,000$ & $31,025,000$ \\
\hline Standard Room & $152,100,000$ & $147,900,000$ \\
\hline Total & $\mathbf{3 4 4 , 4 2 0 , 0 0 0}$ & $\mathbf{3 4 4 , 1 8 0 , 0 0 0}$ \\
\hline
\end{tabular}

Sumber: Hotel Wijaya (diolah)

Berdasarkan tabel diatas maka dapat diuraikan bahwa pendapatan yang diperoleh Hotel Wijaya pada tahun 2019 mengalami penurunan pendapatan dari tahun sebelumnya menjadi sebesar Rp. 344,180,000, penurunan ini disebabkan ada beberapa tipe kamar yang mengalami penurunan penjualan 
yang berdampak langsung terhadap pendapatan Hotel Wijaya.

Tabel 3 Data Operasional Biaya Tahun 2018 dan 2019

\begin{tabular}{|l|l|l|}
\hline Jenis Biaya & $\mathbf{2 0 1 8}$ & $\mathbf{2 0 1 9}$ \\
\hline Biaya Perlengkapan Kamar & $3,543,120$ & $9,151,500$ \\
\hline Biaya Perbaikan dan Perawatan & $5,292,500$ & $21,738,500$ \\
\hline Biaya Gaji dan Upah & $120,000,000$ & $120,000,000$ \\
\hline Biaya Listrik dan Telepon & $15,892,000$ & $15,922,000$ \\
\hline Biaya Bahan Bakar & $3,965,000$ & $5,192,500$ \\
\hline Biaya TV Kabel & $2,040,000$ & $2,100,000$ \\
\hline Biaya Konsumsi Karyawan & $43,800,000$ & $43,800,000$ \\
\hline Biaya Keamanan & $1,720,000$ & $2,148,000$ \\
\hline Biaya Kebersihan & 840,000 & 770,000 \\
\hline Biaya Cetak/Alat Kantor & $2,174,000$ & $2,633,000$ \\
\hline Pajak Hotel & $5,250,000$ & $5,250,000$ \\
\hline THR/Bonus & $12,000,000$ & $12,000,000$ \\
\hline Biaya lain-lain & $10,115,000$ & $8,234,500$ \\
\hline Total Biaya & $\mathbf{2 2 6 , 6 3 1 , 6 2 0}$ & $\mathbf{2 4 8 , 9 4 0 , 0 0 0}$ \\
\hline
\end{tabular}

Sumber: Hotel Wijaya (diolah)

Berdasarkan table diatas maka dapat disimpulkan bahwa 2019 mengalami kenaikan biaya dari tahun 2018 sebesar Rp. 226,631,620 sedangkan tahun 2019 sebesar Rp 247,940,000, ini terjadi karena banyak biaya yang mengalami kenaikan, seperti biaya perlengkapan kamar, biaya bahan bakar, serta biaya perawatan dan perbaikan karena hotel wijaya melakukan beberapa renovasi ruangan kamar.

\section{Alokasi Biaya Variabel dan Biaya Tetap}

Dengan mengidentifikasi alokasi biaya tetap dan variable sebagai dasar untuk mengetahui persentase nilai jual yang mana nantinya dapat memudahkan dalam menentukan margin kontribusi per unit maupun rupiah untuk menghitung break even point.

Tabel 1 Persentase Alokasi Biaya Tetap dan Variabel Hotel Wijaya

\begin{tabular}{|l|c|c|c|c|c|c|}
\hline $\begin{array}{c}\text { Tipe } \\
\text { Kamar }\end{array}$ & $\begin{array}{c}\text { Total } \\
\text { Kamar }\end{array}$ & $\begin{array}{c}\text { Total } \\
\text { dalam } \\
\text { 1 } \\
\text { Tahun }\end{array}$ & $\begin{array}{c}\text { Kapasitas } \\
\text { Kamar } \\
\text { Terjual }\end{array}$ & $\begin{array}{c}\text { Harga } \\
\text { Sewa } \\
\text { Kamar }\end{array}$ & $\begin{array}{c}\text { Kapasitas } \\
\text { Penjualan } \\
\text { Kamar }\end{array}$ & $\begin{array}{c}\text { Persentas } \\
\text { e Nilai } \\
\text { Jual } \\
\text { (\%) }\end{array}$ \\
\hline $\begin{array}{l}\text { Junior } \\
\text { Room }\end{array}$ & 3 & 365 & 1,095 & 60,000 & $65,700,000$ & 7.10 \\
\hline $\begin{array}{l}\text { Single } \\
\text { Room }\end{array}$ & 12 & 365 & 4,380 & 75,000 & $328,500,000$ & 35.50 \\
\hline $\begin{array}{l}\text { Mini } \\
\text { Standard } \\
\text { Room }\end{array}$ & 3 & 365 & 1,095 & 85,000 & $93,075,000$ & 10.06 \\
\hline $\begin{array}{l}\text { Standard } \\
\text { Room }\end{array}$ & 12 & 365 & $\mathbf{4 , 3 8 0}$ & 100,000 & $438,000,000$ & 47.34 \\
\hline Total & $\mathbf{3 0}$ & $\mathbf{1 , 4 6 0}$ & $\mathbf{1 0 . 9 5 0}$ & $\mathbf{3 2 0 , 0 0 0}$ & $\mathbf{9 2 5 , 2 7 5 , 0 0 0}$ & $\mathbf{1 0 0}$ \\
\hline
\end{tabular}

Sumber: Hotel Wijaya (diolah)
Berdasarkan tabel diatas maka dapat disimpulkan bahwa kapasitas total dari penjualan kamar setiap tahunnya yaitu sebesar Rp 925,275,000 yang didapatkan dari potensi kamar terjual tipe junior room sebanyak 1,095 unit, single room 4,380 unit, mini standard room 1,095, dan standard room 4,380 unit.

\section{Alokasi Biaya Tetap}

Tabel 2 Alokasi Biaya Tetap Tahun 2018

\begin{tabular}{|l|c|c|c|}
\hline \multicolumn{1}{|c|}{ Tipe Kamar } & Biaya Tetap & Persentase Alokasi & Jumlah Alokasi \\
\hline Junior Room & & $7.10 \%$ & $13,182,325$ \\
Single Room & $185,651,081$ & $35.50 \%$ & $65,911,626$ \\
Mini Standard Room & & $10.06 \%$ & $18,674,961$ \\
Standard Room & & $47.34 \%$ & $87,882,169$ \\
\hline \multicolumn{1}{|c|}{ Total } & $\mathbf{1 8 5 , 6 5 1 , 0 8 1}$ & $\mathbf{1 0 0} \%$ & $\mathbf{1 8 5 , 6 5 1 , 0 8 1}$ \\
\hline
\end{tabular}

Sumber: Hotel Wijaya (diolah)

Berdasarkan perhitungan alokasi biaya tetap diatas, maka dapat disimpulkan bahwa pada tahun 2018 Hotel Wijaya dengan biaya tetap sebesar Rp 185,651,081 didapatkan dari penjualan kamar tipe junior room dengan alokasi $7.10 \%$ hasil jumlah alokasi terjual sebesar $\mathrm{Rp} 13,182,325$, tipe single room dengan alokasi $35.50 \%$ hasil jumlah alokasi terjual sebesar Rp $65,911,626$, tipe mini standard room dengan alokasi $10.06 \%$ hasil jumlah alokasi terjual sebesar Rp 18,674,961, dan tipe standard room dengan alokasi 47.34\% hasil jumlah alokasi terjual sebesar Rp 87,882,169.

Tabel 3 Alokasi Biaya Tetap Tahun 2019

\begin{tabular}{|l|c|c|c|}
\hline \multicolumn{1}{|c|}{ Tipe Kamar } & Biaya Tetap & Persentase Alokasi & Jumlah Alokasi \\
\hline Junior Room & & $7.10 \%$ & $13,211,953$ \\
Single Room & $186,068,336$ & $35.50 \%$ & $66,059,764$ \\
Mini Standard Room & & $10.06 \%$ & $18,716,933$ \\
Standard Room & & $47.34 \%$ & $88,079,686$ \\
\hline \multicolumn{1}{|c|}{ Total } & $\mathbf{1 8 6 , 0 6 8 , 3 3 6}$ & $\mathbf{1 0 0 \%}$ & $\mathbf{1 8 6 , 0 6 8 , 3 3 6}$ \\
\hline
\end{tabular}

Sumber: Hotel Wijaya (diolah)

Berdasarkan perhitungan alokasi biaya tetap diatas, maka dapat disimpulkan bahwa pada tahun 2018 Hotel Wijaya dengan biaya tetap 
sebesar Rp 186,068,336 didapatkan dari penjualan kamar tipe junior room dengan alokasi $7.10 \%$ hasil jumlah alokasi terjual sebesar Rp 13,211,953, tipe single room dengan alokasi $35.50 \%$ hasil jumlah alokasi terjual sebesar Rp $66,059,764$, tipe mini standard room dengan alokasi $10.06 \%$ hasil jumlah alokasi terjual sebesar Rp 18,716,933, dan tipe standard room dengan alokasi $47.34 \%$ hasil jumlah alokasi terjual sebesar $\quad \mathrm{Rp} \quad 88,079,686$.

\section{Alokasi Biaya Variabel}

Tabel 4 Alokasi Biaya Variabel Hotel Wijaya Tahun 2018

\begin{tabular}{|l|c|c|c|c|c|}
\hline \multicolumn{1}{|c|}{ Tipe Kamar } & $\begin{array}{c}\text { Kapasitas } \\
\text { Kamar } \\
\text { Terjual }\end{array}$ & $\begin{array}{c}\text { Biaya } \\
\text { Variabel }\end{array}$ & $\begin{array}{c}\text { Persentase } \\
\text { Alokasi }\end{array}$ & $\begin{array}{c}\text { Jumlah } \\
\text { Alokasi }\end{array}$ & $\begin{array}{c}\text { Biaya } \\
\text { Variabel } \\
\text { Unit }\end{array}$ \\
\hline Junior Room & 1,095 & & $7.10 \%$ & $2,909,861$ & 2,657 \\
Single Room & 4,380 & $40,980,539$ & $35.50 \%$ & $14,549,304$ & 3,322 \\
Mini Standard Room & 1,095 & & $10.06 \%$ & $4,122,303$ & 3,765 \\
Standard Room & 4,380 & & $47.34 \%$ & $19,399,072$ & 4,429 \\
\hline \multicolumn{1}{|c|}{ Total } & $\mathbf{1 0 , 9 5 0}$ & $\mathbf{4 0 , 9 8 0 , 5 3 9}$ & $\mathbf{1 0 0 \%}$ & $\mathbf{4 0 , 9 8 0 , 5 3 9}$ & $\mathbf{1 4 , 1 7 3}$ \\
\hline
\end{tabular}

Sumber: Hotel Wijaya (diolah)

Berdasarkan perhitungan alokasi biaya variabel diatas, maka dapat disimpulkan bahwa pada tahun 2018 Hotel Wijaya memiliki biaya variable sebesar Rp 40,980,539 dan biaya variable per unit sebanyak 14,173 unit didapatkan dari penjualan kamar tipe junior room dengan alokasi $7.10 \%$ hasil jumlah alokasi terjual sebesar Rp $2,909,861$ dan biaya variable per unit sebanyak 2,657 unit, tipe single room dengan alokasi $35.50 \%$ hasil jumlah alokasi terjual sebesar Rp 14,549,304 dan biaya variable per unit sebanyak 3,322 unit, tipe mini standard room dengan alokasi $10.06 \%$ hasil jumlah alokasi terjual sebesar Rp 4,122,303 dan biaya variable per unit sebanyak 3,765 unit, terakhir tipe standard room dengan alokasi $47.34 \%$ hasil jumlah alokasi terjual sebesar Rp 19,399,072 dan biaya variable per unit sebanyak 4,429 unit.
Tabel 5 Alokasi Biaya Variabel Hotel Wijaya Tahun 2019

\begin{tabular}{|l|c|c|c|c|c|}
\hline \multicolumn{1}{|c|}{ Tipe Kamar } & $\begin{array}{c}\text { Kapasitas } \\
\text { Kamar } \\
\text { Terjual }\end{array}$ & $\begin{array}{c}\text { Biaya } \\
\text { Variabel }\end{array}$ & $\begin{array}{c}\text { Persentase } \\
\text { Alokasi }\end{array}$ & $\begin{array}{c}\text { Jumlah } \\
\text { Alokasi }\end{array}$ & $\begin{array}{c}\text { Biaya } \\
\text { Variabel } \\
\text { /Unit }\end{array}$ \\
\hline Jumior Room & 1,095 & & $7.10 \%$ & $4,464,260$ & 4,077 \\
Single Room & 4,380 & $62,871,664$ & $35.50 \%$ & $22,321,301$ & 5,096 \\
Mini Standard Room & 1,095 & & $10.06 \%$ & $6,324,369$ & 5,776 \\
Standard Room & 4,380 & & $47.34 \%$ & $29,761,734$ & 6,795 \\
\hline \multicolumn{1}{|c|}{ Total } & $\mathbf{1 0 , 9 5 0}$ & $\mathbf{6 2 , 8 7 1 , 6 6 4}$ & $\mathbf{1 0 0 \%}$ & $\mathbf{6 2 , 8 7 1 , 6 6 4}$ & $\mathbf{2 1 , 7 4 4}$ \\
\hline
\end{tabular}

Sumber: Hotel Wijaya (diolah)

Berdasarkan perhitungan alokasi biaya variabel diatas, maka dapat disimpulkan bahwa pada tahun 2019 Hotel Wijaya memiliki biaya variable sebesar Rp 62,871,664 dan biaya variable per unit sebanyak 4,077 unit didapatkan dari penjualan kamar tipe junior room dengan alokasi $7.10 \%$ hasil jumlah alokasi terjual sebesar $\mathrm{Rp}$ $4,464,260$ dan biaya variable per unit sebanyak 2,657 unit, tipe single room dengan alokasi $35.50 \%$ hasil jumlah alokasi terjual sebesar Rp 22,321,301 dan biaya variable per unit sebanyak 5,096 unit, tipe mini standard room dengan alokasi $10.06 \%$ hasil jumlah alokasi terjual sebesar Rp 6,324,369 dan biaya variable per unit sebanyak 5,776 unit, terakhir tipe standard room dengan alokasi $47.34 \%$ hasil jumlah alokasi terjual sebesar Rp 29,761,734 dan biaya variable per unit sebanyak 21,744 unit.

\section{Margin Kontribusi}

Sebelum melakukan analisis impas, terlebih dahulu harus mengetahui margin kontribusi yang mana akan digunakan untuk menutup biaya tetap. Ketika margin kontribusi tidak mampu menutup biaya tetap, maka perusahaan bisa dikatakan rugi. Berikut perhitungan margin kontribusi pada Hotel Wijaya tahun 2018 dan 2019: 
Tabel 6 Margin Kontribusi Hotel Wijaya Tahun 2018

\begin{tabular}{|l|c|c|c|c|c|c|}
\hline \multicolumn{1}{|c|}{ Tipe Kamar } & $\begin{array}{c}\text { Harga } \\
\text { Jual/Tnit }\end{array}$ & $\begin{array}{c}\text { Biaya } \\
\text { Variabel } \\
\text { Unit }\end{array}$ & $\begin{array}{c}\text { Margin } \\
\text { Kontribusi }\end{array}$ & $\begin{array}{c}\text { Biaya } \\
\text { Variabel }\end{array}$ & Penjualan & $\begin{array}{c}\text { RCM } \\
\text { (\%) }\end{array}$ \\
\hline Junior Room & 60,000 & 2,657 & 57,343 & $2,909,861$ & $23,520,000$ & 0.8763 \\
Single Room & 75,000 & 3,322 & 71,678 & $14,549,304$ & $130,125,000$ & 0.8882 \\
Mini Standard Room & 85,000 & 3,765 & 81,235 & $4,122,303$ & $38,675,000$ & 0.8934 \\
StandardRoom & 100,000 & 4,429 & 95,571 & $19,399,072$ & $152,100,000$ & 0.8725 \\
\hline
\end{tabular}

Sumber: Hotel Wijaya (diolah)

Berdasarkan perhitungan margin kontribusi diatas, maka dapat disimpulkan bahwa pada tahun 2018 margin kontribusi Hotel Wijaya yaitu junior room sebesar Rp 57,343 dengan ratio contribution margin $88 \%$, single room sebesar $\mathrm{Rp} 71,678$ dengan ratio contribution margin $89 \%$, mini standard room sebesar $\mathrm{Rp} 81,235$ dengan ratio contribution margin $89 \%$ dan standard room sebesar $\mathrm{Rp}$ 95,571 dengan ratio contribution margin $87 \%$.

Tabel 7Margin Kontribusi Hotel Wijaya Tahun 2019

\begin{tabular}{|l|c|c|c|c|c|c|}
\hline \multicolumn{1}{|c|}{ Tipe Kamar } & $\begin{array}{c}\text { Harga } \\
\text { Jual/Unit }\end{array}$ & $\begin{array}{c}\text { Biaya } \\
\text { Variabel/ } \\
\text { Unit }\end{array}$ & $\begin{array}{c}\text { Margin } \\
\text { Kontribusi }\end{array}$ & $\begin{array}{c}\text { Biaya } \\
\text { Variabel }\end{array}$ & Penjualan & $\begin{array}{c}\text { RCM } \\
(\%)\end{array}$ \\
\hline Jumior Room & 60,000 & 4,077 & 55,923 & $4,464,260$ & $19,380,000$ & 0.7696 \\
Single Room & 75,000 & 5,096 & 69,904 & $22,321,301$ & $145,875,000$ & 0.8470 \\
Mini Standard Room & 85,000 & 5,776 & 79,224 & $6,324,369$ & $31,025,000$ & 0.7962 \\
Standard Room & 100,000 & 6,795 & 93,205 & $29,761,734$ & $147,900,000$ & 0.7988 \\
\hline
\end{tabular}

Sumber: Hotel Wijaya (diolah)

Berdasarkan perhitungan margin kontribusi diatas, maka dapat disimpulkan bahwa pada tahun 2019 margin kontribusi Hotel Wijaya yaitu junior room sebesar Rp 55,923 dengan ratio contribution margin $83 \%$, single room sebesar $\mathrm{Rp}$ 69,904 dengan ratio contribution margin $85 \%$, mini standard room sebesar Rp 79,224 dengan ratio contribution margin $85 \%$ dan standard room sebesar Rp 93,205 dengan ratio contribution margin $81 \%$.

\section{Analisis Break Event Point}

Dengan penggunaan data-data biaya operasional serta data penjualan tahun 2018 dan 2019, maka bisa dihitung berapa titik impas dalam rupiah setiap tahun. Lebih dari itu akan diperoleh juga besarnya laba atau kerugian yang didapatkan oleh perusahaan selama periode tersebut. Hasil perhitungan ini bisa digunakan sebagai penilaian sejauh

$$
\begin{aligned}
& \text { Break Event Point Tahun } 2018 \\
& \mathrm{BEP}_{2018} \text { (Dalam Unit) }=\frac{\text { Biaya Tetap }}{\text { Margin Kontribusi Per Unit }} \\
& \text { 1. Sunior Room } \mathrm{BEP}_{2018}=\frac{13,182,325}{57,343}=230 \text { Unit (dibulatkan) } \\
& \text { 2. Single Room } \mathrm{BEP}_{2018}=\frac{65,911,626}{71,678}=920 \text { Unit (dibulatkan) } \\
& \text { 3. Mini Standard Room } \mathrm{BEP}_{2018}=\frac{18,674,961}{81,235}=230 \text { Unit (dibulatkan) } \\
& \text { 4. Standard Room } \mathrm{BEP}_{2018}=\frac{87,882,169}{95,571}=920 \text { Unit (dibulatkan) } \\
& \mathrm{BEP}_{2018} \text { (Dalam Rupiah) }=\frac{\mathrm{Biaya} \text { Tetap }}{\mathrm{Rasio}_{\mathrm{Margin}} \text { Kontribusi }} \\
& \text { 1. Junior Room } \mathrm{BEP}_{2018}=\frac{13,182,325}{0.8763}=\mathrm{Rp} 15,043,484 \\
& \text { 2. Single Room } \mathrm{BEP}_{2018}=\frac{65,911,626}{0.8882}=\mathrm{Rp} 74,208,944 \\
& \text { 3. Mini Standard Room } \mathrm{BEP}_{2018}=\frac{18,674,961}{0.8934}=\mathrm{Rp} 20,902,973 \\
& \text { 4. Standard Room } \mathrm{BEP}_{2018}=\frac{87,882,169}{0.8725}=\mathrm{Rp} 100,729,347
\end{aligned}
$$

Dari perhitungan dan tabel diatas, maka dapat disimpulkan bahwa jumlah break even point Hotel Wijaya pada tahun 2018 sebesar Rp $210,884,748$, yang mana berarti jika Hotel Wijaya menginginkan tidak memperoleh keuntungan maupun kerugian maka harus memperoleh penjualan kamar sebanyak 2.300 unit dan pendapatan sebesar $\mathrm{Rp}$ $210,884,748$, yang terdiri atas junior room sebanyak 230 unit dengan pendapatan sebesar $\mathrm{Rp} 15,043,484$, single room sebanyak 920 unit dengan pendapatan sebesar Rp 74,208,944, mini standard room sebanyak 230 unit dengan pendapatan sebesar Rp 20,902,973 dan standard room sebanyak 920 unit dengan pendapatan $\mathrm{Rp}$ $100,729,347$. 


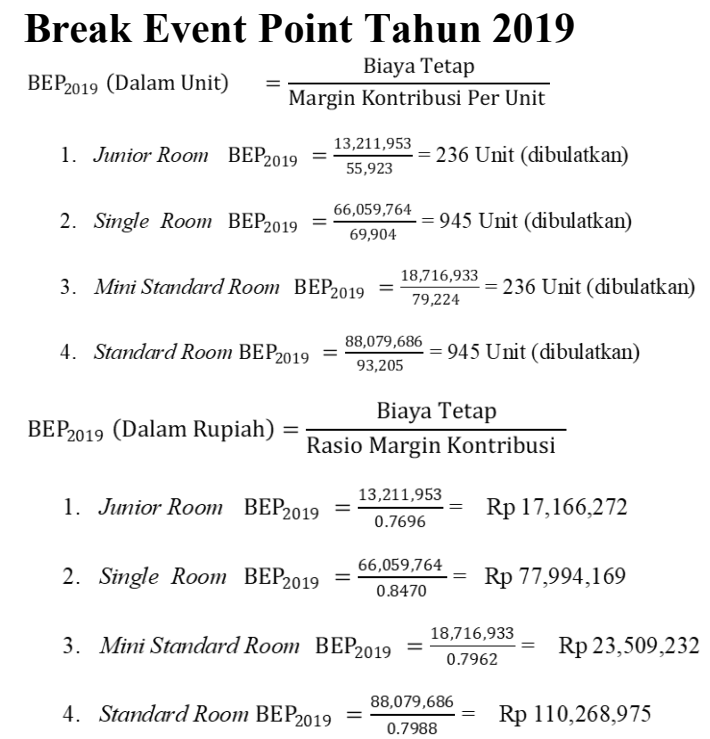

Dari perhitungan dan tabel diatas, maka dapat disimpulkan bahwa jumlah break even point Hotel Wijaya pada tahun 2019 sebesar Rp 219,399,020, yang mana berarti jika Hotel Wijaya menginginkan tidak memperoleh keuntungan maupun kerugian maka harus memperoleh penjualan kamar sebanyak 2.362 unit dan pendapatan sebesar Rp 17,166,272, yang terdiri atas junior room sebanyak 236 unit dengan pendapatan sebesar $\mathrm{Rp}$ $77,994,169$, single room sebanyak 945 unit dengan pendapatan sebesar $\mathrm{Rp}$ 23,509,232, mini standard room sebanyak 236 unit dengan pendapatan sebesar Rp 21,973,389 dan standard room sebanyak 945 unit dengan pendapatan $\mathrm{Rp} 100,729,347$.

\section{Laba Tahun 2018}

$$
\begin{aligned}
\mathrm{Laba}_{2018} & =\text { Total Pendapatan }- \text { Total Biaya } \\
& =\operatorname{Rp} 344,420,000-\mathrm{Rp} \mathrm{226,631,620} \\
& =\operatorname{Rp~117,788,380}
\end{aligned}
$$

Berdasarkan perhitungan diatas, maka dapat diuraikan bahwa laba pada tahun 2018 sebesar Rp 117,788,380 yang diperoleh dari pendapatan tahun 2018 sebesar Rp 344,420,000 dan total biaya yang dikeluarkan sebesar $\mathrm{Rp}$ $226,631,620$.

\section{Laba Tahun 2019}

$$
\begin{aligned}
\text { Laba }_{2019} & =\text { Total Pendapatan }- \text { Total Biaya } \\
& =\operatorname{Rp} 344,180,000-\operatorname{Rp} 248,940,000 \\
& =\operatorname{Rp} 95,240,000
\end{aligned}
$$

Berdasarkan perhitungan diatas, maka dapat diuraikan bahwa laba pada tahun 2019 sebesar Rp 95,240,000 yang diperoleh dari pendapatan tahun 2019 sebesar Rp 344,180,000 dan total biaya yang dikeluarkan sebesar $\mathrm{Rp}$ 248,940,000.

Berdasarkan analisis perhitungan biaya dan laba diatas maka Hotel Wijaya pada tahun 2018 sebesar mengalami kenaikan kembali menjadi sebesar Rp 117,788,380 pada tahun 2019 mendapati turunnya kembali laba menjadi sebesar Rp 95,240,000. Penurunan laba tahun terjadi diakibatkan adanya renovasi, untuk tahun selanjutnya diharapkan terus mengalami kenaikan

\section{Profit Planning dengan Analisis Titik Impas (Break Even Point)}

Dengan analisis titik impas, maka bisa diketahui perencanaan laba yang sesuai yang merupakan tujuan yg wajib dicapai perusahaan. Kalau perusahaan melakukan perencanaan laba untuk mendapatkan laba, maka perusahaan harus bisa meningkatkankan volume penjualan diatas titik impas.

Menurut hasil wawancara bahwa pada tahun 2020 Hotel Wijaya mengharapkan kenaikan sebesar $10 \%$ dan minimal tidak mendapati turunnya laba dari tahun sebelumnya (tahun 2019). Besarnya target laba yang diharpakan pada tahun 2020 merujuk pada laba tahun 2019. 
Laba tahun $2019=\mathrm{Rp} 95,240,000$

Kenaikan laba yang diharapkan

$=\operatorname{Rp} 95,240,000 \times 10 \%$

$=9,524,000$

Rencana laba tahun 2020

$=$ laba tahun $2019+$ kenaikan $10 \%$

$=95,240,000+9,524,000$

$=\operatorname{Rp} 104,764,000$

Setelah diketahuinya keuntungan atau laba yang diinginkan tercapai, maka selanjutnya penjualan yang wajib dicapai supaya Hotel Wijaya bisa memperoleh laba yang ditargetkan. Berikut penjualan dalam rupiah pada keuntungan (laba) yang direncanakan:

$$
\begin{aligned}
\text { Penjualan }(\text { Rupiah }) & =\frac{F C+\text { Laba yang direncanakan }}{1-\frac{V C}{S}} \\
& =\frac{186,068,336+104,764,000}{1-\frac{62,871,664}{344,180,000}} \\
& =\frac{290,832,336}{1-0.182671} \\
& =\frac{290,832,336}{0.817329}=\operatorname{Rp} 355,832,589
\end{aligned}
$$

Sedangkan untuk penjualan dalam unit bisa dihitung dengan perhitungan berikut:

$$
\begin{aligned}
\text { Penjualan }(\text { Unit })= & \frac{F C+\text { Laba yang direncanakan }}{\text { Margin Kontribusi } / \text { unit }} \\
& =\frac{186,068,336+104,764,000}{298,256} \\
& =\frac{290,832,336}{298,256}=975 \text { unit }
\end{aligned}
$$

Berdasarkan perhitungan diatas diperoleh penjualan unit kamar sebanyak 975 unit, jika merujuk kepada BEP tahun 2019 yang mana sebanyak 2.320 Unit, maka angka ini tidak sesuai karena seharusnya lebih besar dari BEP apalagi jika ditambah laba sebesar $10 \%$. Oleh karena itu peneliti melakukan perhitungan dengan menggunakan susunan penjualan kamar dan susunan jumlah kamar yang dijual. Untuk susunan penjualan jika Hotel Wijaya merencanakan keuntungan sebesar $10 \%$ maka dapat dilihat pada tabel dibawah ini.

Tabel 8 Penyusunan Penjualan per tipe Kamar Hotel Wijaya Untuk Tahun 2020 Pada Perencanaan Laba 10\% Dari Penjualan

\begin{tabular}{|l|c|c|c|}
\hline \multicolumn{1}{|c|}{ Tipe Kamar } & $\begin{array}{c}\text { Tingkat } \\
\text { Penjualan }\end{array}$ & $\begin{array}{c}\text { Persentase } \\
\text { Alokasi }\end{array}$ & $\begin{array}{c}\text { Penyusunan } \\
\text { Penjualan (Rupiah) }\end{array}$ \\
\hline Junior Room & & $7.10 \%$ & $25,266,219$ \\
Single Room & $355,832,589$ & $35.50 \%$ & $126,331,097$ \\
Mini Standard Room & & $10.06 \%$ & $35,793,811$ \\
StandardRoom & & $47.34 \%$ & $168,441,462$ \\
\hline \multicolumn{1}{|c|}{ Total } & $\mathbf{3 5 5 , 8 3 2 , 5 8 9}$ & $\mathbf{1 0 0} \%$ & $\mathbf{3 5 5 , 8 3 2 , 5 8 9}$ \\
\hline
\end{tabular}

Sumber: Hotel Wijaya (diolah)

Tabel 9Penyusunan Kamar Yang Dijual Untuk Tahun 2020 Pada Perencanaan Laba 10\% Dari Penjualan

\begin{tabular}{|l|c|c|c|}
\hline \multicolumn{1}{|c|}{ Tipe Kamar } & $\begin{array}{c}\text { Penyusunan } \\
\text { Penjualan (Rupiah) }\end{array}$ & $\begin{array}{c}\text { Harga } \\
\text { Kamar }\end{array}$ & $\begin{array}{c}\text { Penyusunan } \\
\text { Penjualan (Unit) }\end{array}$ \\
\hline Junior Room & $25,266,219$ & 60,000 & 421 \\
Single Room & $126,331,097$ & 75,000 & 1,684 \\
Mini Standard Room & $35,793,811$ & 85,000 & 421 \\
Standard Room & $168,441,462$ & 100,000 & 1,684 \\
\hline \multicolumn{1}{|c|}{ Total } & $\mathbf{3 5 5 , 8 3 2 , 5 8 9}$ & & $\mathbf{4 , 2 1 1}$ \\
\hline
\end{tabular}

Sumber: Hotel Wijaya (diolah)

Berdasarkan perhitungan diatas maka dapat disimpulkan bahwa jika Hotel Wijaya pada tahun 2020 mengharapkan mendapatkan laba sebesar Rp 104,764,000, maka untuk memperoleh laba tersebut Hotel Wijaya harus bisa menyewakan kamar dengan penjualan sebesar $\mathrm{Rp} 355,832,589$ atau dengan unit terjual sebanyak 4.211 unit kamar dengan tipe junior room sebanyak 421 unit, tipe single room sebanyak 1,684 unit, tipe mini standard room 421 unit dan tipe standard room sebanyak 1,684 unit.

Berdasarkan dari perolehan perhitungan yang dilakukan oleh penulis maka perhitungan BEP Unit dengan rumus:

$$
\begin{gathered}
\text { BEP }(\text { Dalam Rupiah })=\frac{\text { Biaya Tetap }}{\text { Rasio Margin Kontribusi }} \\
\text { Rumus diatas tidak sesuai }
\end{gathered}
$$
karena seharusnya hasil lebih besar dari 
BEP tahun sebelumnya apalagi jika ditambah kenaikan laba. Oleh karena itu penulis melakukan perhitungan kembali berdasarkan susunan penjualan kamar dan susunan jumlah kamar yang dijual, perhitungan mengacu terhadap jurnal menurut Candra Romanda. Maka diperoleh hasil yang sesuai dengan teori yang dipaparkan oleh Hansen dan Mowen bahwa Analisis break event point merupakan suatu alat yang sangat berguna untuk perencanaan dan pengambilan keputusan. Dan juga sesuai dengan teori yang telah dipaparkan oleh Utari et al., (2016) dan Ravelly (2016) bahwa BEP merupakan salah satu alat untuk membuat perencanaan laba, dapat digunakan pihak manajemen sebagai teknik planning, control, decision making dalam aktivitas perusahaan untuk mencapai laba, serta menyongsong perubahan yang mungkin terjadi atas, harga penjualan dan biaya yang dikeluarkan.

\section{PENUTUP}

\section{Kesimpulan}

Berdasarkan hasil penelitian yang telah peneliti lakukan dengan tujuan menganalisis profit planning dengan menggunakan analisis break event point dan margin of safety pada Hotel Wijaya, dapat disimpulkan bahwa:

1. Hotel Wijaya pada tahun 2018 mendapatkan laba sebesar Rp 117,788,380 tetapi pada tahun 2019 mendapati turunnya kembali laba menjadi sebesar Rp 95,240,000. Penurunan terjadi karena adanya renovasi.

2. Menurut data tahun 2018, Hotel Wijaya telah mencapai titik impas dengan jumlah BEP sebesar Rp $210,884,748$ dan tingkat volume penjualan kamar sebanyak 2.300 unit dan Menurut data tahun 2019,
Hotel Wijaya telah mencapai titik impas dengan jumlah BEP sebesar Rp 219,399,020 dan tingkat volume penjualan kamar sebanyak 2.362 unit.

3. Hotel Wijaya merencanakan keuntungan (profit planning) pada tahun 2020 dengan persentase sebesar $10 \%$ dengan jumlah sebesar 104,764,000. Dengan demikian, untuk memperoleh laba tersebut Hotel Wijaya harus bisa menyewakan kamar dengan penjualan sebesar Rp 355,832,589 dengan unit terjual sebanyak 4.211 unit.

\section{Saran}

Berdasarkan simpulan dan fakta yang didapatkan dari penelitian ini, maka saran yang bisa diberikan sebagai tahap untuk menindak lanjuti dari hasil penelitian ini. Saran yang diberikan yaitu saran atas keterbatasan dan kekurangan yang ada supaya bisa diperbaiki dan dikembangkan di periode yang akan datang, adapun sarannya ialah sebagai berikut:

1. Hotel Wijaya harus lebih memperhatikan pengeluaran yang ada terutama biaya lain-lain harus dilakukan penurunan.

2. Hotel Wijaya harus lebih memperhatikan masalah perencanaan terutama perencanaan laba karena supaya perusahaan lebih maju dan berkembang.

3. Hotel Wijaya harus melakukan renovasi secara menyeluruh serta penataan interior design supaya konsumen lebih tertarik untuk menginap dan juga pelayanan harus lebih ditingkatkan kembali.

4. Hotel Wijaya harus dapat menenerapkan analisis break event point supaya dapat memudahkan dalam melakukan perencanaan laba kedepannya. 
5. Untuk penelitian lanjutan diharapkan dapat melakukan penelitian yang berkaitan dengan analisis biaya tetap dan biaya variable supaya dapat meningkatkan keuntungan (laba) perusahaan terutama hotel, karena biaya tetap dan biaya variable merupakan factor penting yang berpengaruh terhadap laba.

\section{DAFTAR PUSTAKA}

Adisaputro, G., \& Anggraini, Y. (2017). Anggaran Bisnis (Analisis, Perencanaan, dan pengendalian Laba) (1st ed.). UPP STIM YKPN.

Hansen, D., R., \& Mowen, M., M. (2009). Managerial Accounting (D. Artos (ed.); 8th ed.). Salemba Empat.

Ravelly, H. (2016). Analisis Break Even Point Sebagai Dasar Perencanaan Laba pada Hotel Metro Banjarmasin. Journal of Chemical Information and Modeling, 5(2)
Romanda, C. (2017). Break Even Point Sebagai Alat Perencanaan Laba Hotel (Studi Kasus Hotel Ranggonang Sekayu). Jurnal Riset Akuntansi Dan Manajemen Malahayati, 6(1), 1-10.

Sujarweni, W. (2019). Metodologi Penelitian Bisnis \& Ekonomi. Pustaka Baru Press.

Sunanto. (2016). Analisis Break Even Point dalam Menentukan Harga Sewa Kamar pada Hotel Ranggonang Sekayu. Jurnal Auntansi Politeknik Sekayu (ACSY), 5(9), 1689-1699.

Utari, D., Purwanti, A., \& Prawironegoro, D. (2016). Akuntansi Manajemen (Pendekatan Praktis) (4th ed.). Mitra Wacana Media. 